\title{
POPULATION TRENDS AND COMMUNITY COMPOSITION OF MIGRATORY WATERBIRDS IN THREE EMERGING WETLANDS OF GLOBAL SIGNIFICANCE IN SOUTHWESTERN BENGAL, INDIA
}

\section{T.N. Khan ${ }^{1}$, Anirban Sinha ${ }^{2}$ \& Prantik Hazra ${ }^{3}$}

${ }^{1,2,3}$ Ecology and Wildlife Biology Laboratory, Department of Zoology, Maulana Azad College, 8 Rafi Ahmed Kidwai Road, Kolkata, West Bengal 700013, India

${ }^{1}$ taraknk@gmail.com (corresponding author), ${ }^{2}$ arupexpress@hotmail.com, ${ }^{3}$ prantik1234@yahoo.co.in

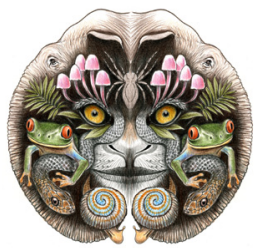

ISSN 0974-7907 (Online) ISSN 0974-7893 (Print)

OPEN ACCESS

Abstract: We studied the diversity, abundance and population trends in three flourishing wetlands of southern Bengal over 16 years. These wetlands constituted a major shift from the present scenario of overall wetland deterioration, including monotonous declines in important winter visitors prevailing in surrounding wetlands, especially in Tilpara Reservoir and Purulia Saheb Bandh Lake. All the three wetlands support rich waterbird diversity and almost all of them tend to exhibit consistently stable or increasing trends in their populations during the course of the study. The waterbird communities did not differ greatly during the study period and were tending to arrive at their equilibria. These wetlands consistently support strong waterbird food-bases, which may support rich diversity. Since, they have already been supporting increasing or stable populations of a majority of the important waterbird species they are expected to emerge as important waterbird abodes in northeastern India very soon, provided we keep them undisturbed and allow them to follow their own course.

Keywords: Community composition, diversity estimates, habitat attributes, habitat expansion, population trends, waterbird abundance.

DOI: http://dx.doi.org/10.11609/jott.2652.8.3.8541-8555 | ZooBank: urn:Isid:zoobank.org:pub:775F1CBC-6683-4504-B16B-0B929887BD01

Editor: S. Balachandran, Bombay Natural History Society, Mumbai, India.

Date of publication: 26 March 2016 (online \& print)

Manuscript details: Ms \# 4109 | Received 09 September 2015 | Final received 13 February 2016 | Finally accepted 08 March 2016

Citation: Khan, T.N., A. Sinha \& P. Hazra (2016). Population trends and community composition of migratory waterbirds in three emerging wetlands of global significance in southwestern Bengal, India. Journal of Threatened Taxa 8(3): 8541-8555; http://dx.doi.org/10.11609/jott.2652.8.3.8541-8555

Copyright: (C) Khan et al. 2016. Creative Commons Attribution 4.0 International License. JoTT allows unrestricted use of this article in any medium, reproduction and distribution by providing adequate credit to the authors and the source of publication.

Funding: A part of this study (2004-2006 and 2008-2011) was partially funded by UGC.

Conflict of Interest: The authors declare no competing interests. Funding sources had no role in study design, data collection, results interpretation and manuscript writing.

Author Details: T.N. KHAN worked as the supervisor and Principal Investigator of South Bengal Waterbird Project and was an Associate Professor in the Department of Zoology, Maulana Azad College, Kolkata, and presently is continuing research as a Guest Faculty in the same Department. ANIRBAN SINHA worked as a CSIR Research Fellow in the project and is presently continuing research on waterbirds at the Department of Zoology, Maulana Azad College, Kolkata. PRANTIK HAZRA worked as a UGC Research Fellow in the project and is continuing research in the same Department. Presently he is and Assistant Professor of Zoology in West Bengal Educational Service.

Author Contribution: TNK conceived and supervised the project, analysed the data, interpreted the results and wrote the paper. AS and PH conducted field works, collected data and assisted TNK in the data analysis.

Acknowledgments: Authors acknowledge UGC for funding a part of this study; Principal, Maulana Azad College for the facilities; PG students at Maulana Azad College for participating in survey works; and local fishermen communities, fisheries managers, local authorities and NGOs for active cooperation in carrying out this study and providing important information about the wetlands and their denizens. A.S. and P.H. thank CSIR and UGC respectively for their research fellowships.

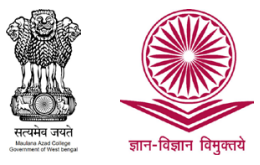




\section{INTRODUCTION}

Wetlands provide vital habitats for waterbirds. However, man has caused destruction and degradation of wetlands worldwide (Moser et al. 1996). Almost half the world's natural wetlands, including those from India, have disappeared in the last century due to imprudent anthropogenic activities, while the others are variously affected (Shine \& Klemm 1999; Khan et al. 2005; Sinha et al. 2011). Parallelly, artificial wetlands such as ponds, man-made lakes, reservoirs have increased worldwide, and these provide alternative, often suitable, habitats for waterbirds (Elphick \& Oring 1998; Elphick 2000; Tourenq et al. 2001; Ma et al. 2004; Okes et al. 2008; Rendon et al. 2008; Sinha et al. 2012). However, the net consequences of such habitat transformation for waterbirds remain inconclusive (Day \& Colwell 1998; Elphick 2000; Ma et al. 2004). In fact, we have very little information about the waterbird species which are capable of adopting such transformed habitats, and which fail to do so.

The wetlands in southern Bengal, especially Tilpara Reservoir and Purulia Saheb Bandh Lake, have long been recognised as important habitats for waterbirds, especially for many long-distance migrants. An increase in wetland coverage occurred in the region with the creation of the Hinglo Reservoir in 1976 and Bakreswar Reservoir in 1998 (Sinha et al. 2011). Gradual deterioration of most of the wetlands in southern Bengal, particularly Tilpara Reservoir and Purulia Saheb Bandh Lake, and the creation of new waterbird habitats have resulted in a notable change in the waterbird community composition (Khan 2010; Sinha et al. 2011). No comprehensive information of the region, however, is available and the published data are restricted to a few census reports of Tilpara Reservoir (Wetlands International 2009) and some aspects of waterbird population and community structure of Bakreswar and Tilpara reservoirs (Sinha et al. 2011, 2012).

In this paper, we have tried to present the first detailed analysis of population trends and community composition of migratory waterbirds in three important wetlands of southern Bengal. In sharp contrast to the prevailing scenario of waterbird declines in the surrounding wetlands (Sinha et al. 2011), these abodes showed stable to increasing waterbird population trends over the 16-year course of this study. Our main objectives were: (1) to analyse the waterbird diversity and assemblages in these wetlands; (2) to identify longterm trends for each waterbird species there; (3) to consider the conservation implications of our findings.

\section{MATERIAL AND METHODS}

\section{Study area}

The study was conducted in three important wetlands spread over Birbhum and Purulia districts of West Bengal (Fig. 1 and Image 1). These wetlands were:

1. Bakreswar Reservoir: The reservoir was created in 1998 by erecting a dam on the Bakreswar River for providing water to Bakreswar Thermal Power Plant and the waterbirds began to arrive in large numbers from 2001 onwards. The wetland is rich in macrophytes, especially in Sedge (Scirpus spp.) and Reed (Fragmites sp.), and a rich diversity of arthropods, molluscs and fish that provide rich grazing for the waterbirds. The security personnel of the thermal power plant protect the reservoir along with its denizens with particular emphasis on the area near the dam. However, fishermen and tourists often create disturbance to the birds there.

2. Hinglo Reservoir: Situated near the West BengalJharkhand border at about $20 \mathrm{~km}$ west of Bakreswar this reservoir was formed by erecting an irrigation dam on Hinglo River in 1976. It is very similar to Bakreswar Reservoir in nature, and floral and faunal composition. Its position in the rural area and protection rendered by the irrigation authority allow the wetland to serve as a rich waterbird abode in southwestern Bengal.

3. Adra Saheb Bandh Lake: Created in 1848 mainly for supplying potable water to Adra Township, this wetland is situated $3 \mathrm{~km}$ northeast of Adra Railway Station. It is surrounded by the Kang forest in the northern part, the proposed Adra Thermal Power Plant in the southwestern part, grassland and cropland in the eastern and southern parts. The wetland is very rich in macrophytes, macroinvertebrates and fish that support numerous residential and migratory waterbirds especially in winter. Various tourism activities, especially in winter, constitute a source of disturbance to the waterbirds.

The geographic location and other information of these wetlands relevant for the purpose of this study are summarised in Appendix 1.

\section{Waterbird census}

To coincide with large-scale Asian Waterfowl Census Programme (AWC) coordinated by Wetlands International, waterbirds were counted species-wise during January of each year from 1998 to 2013. Therefore, a total of 48 censuses for each species was made during the course of this study (i.e., for each species, $n=3$ wetlands $x 16$ years $=48$ ). Since, Bakreswar and Hinglo Reservoirs were closely located (within $22 \mathrm{~km}$ ) they were censused at the same time and date to avoid possible 


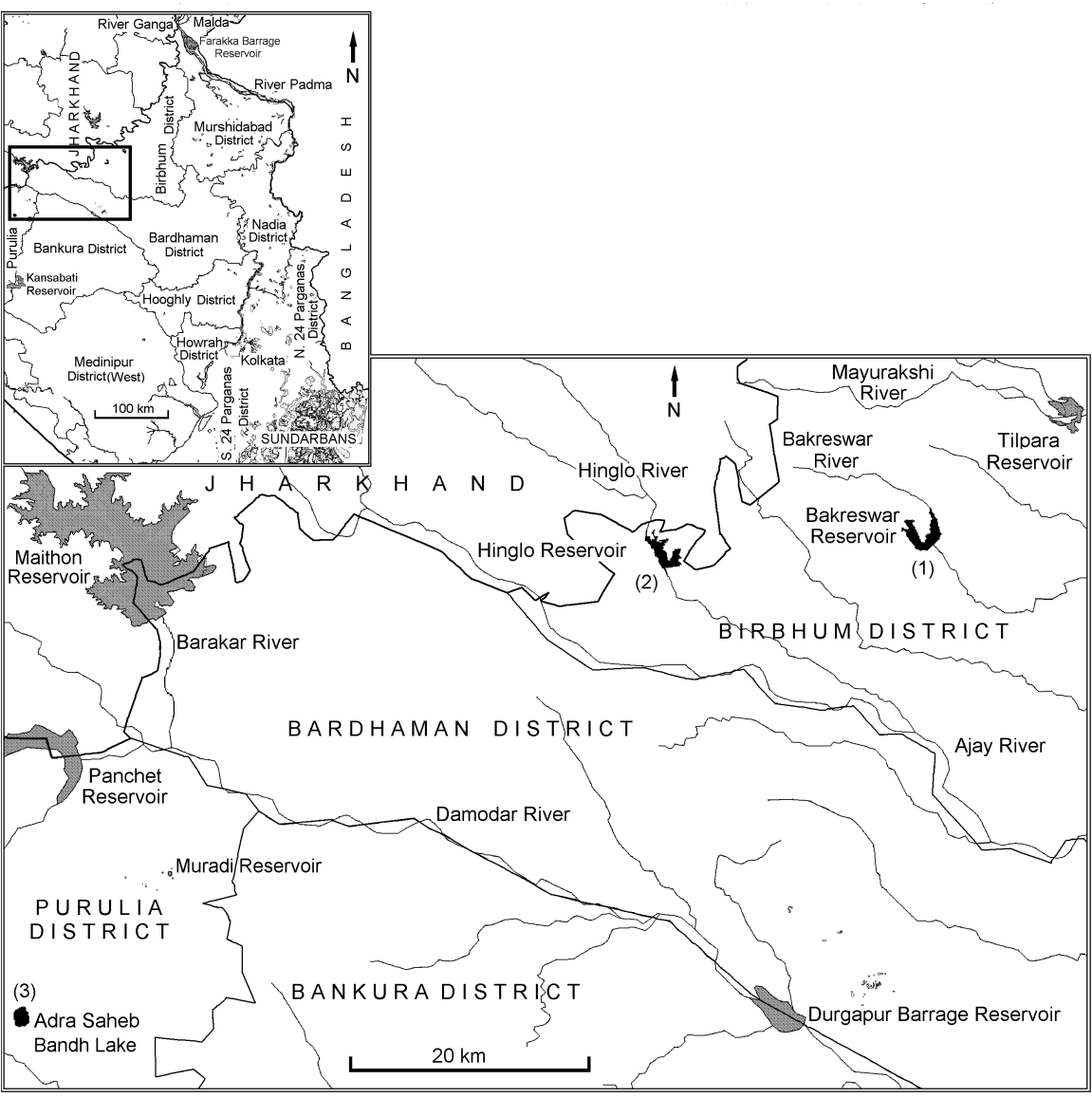

Figure 1. The study area with a map of southern Bengal in the inset. The wetlands under study are highlighted with solid black colour (1,2 and 3).
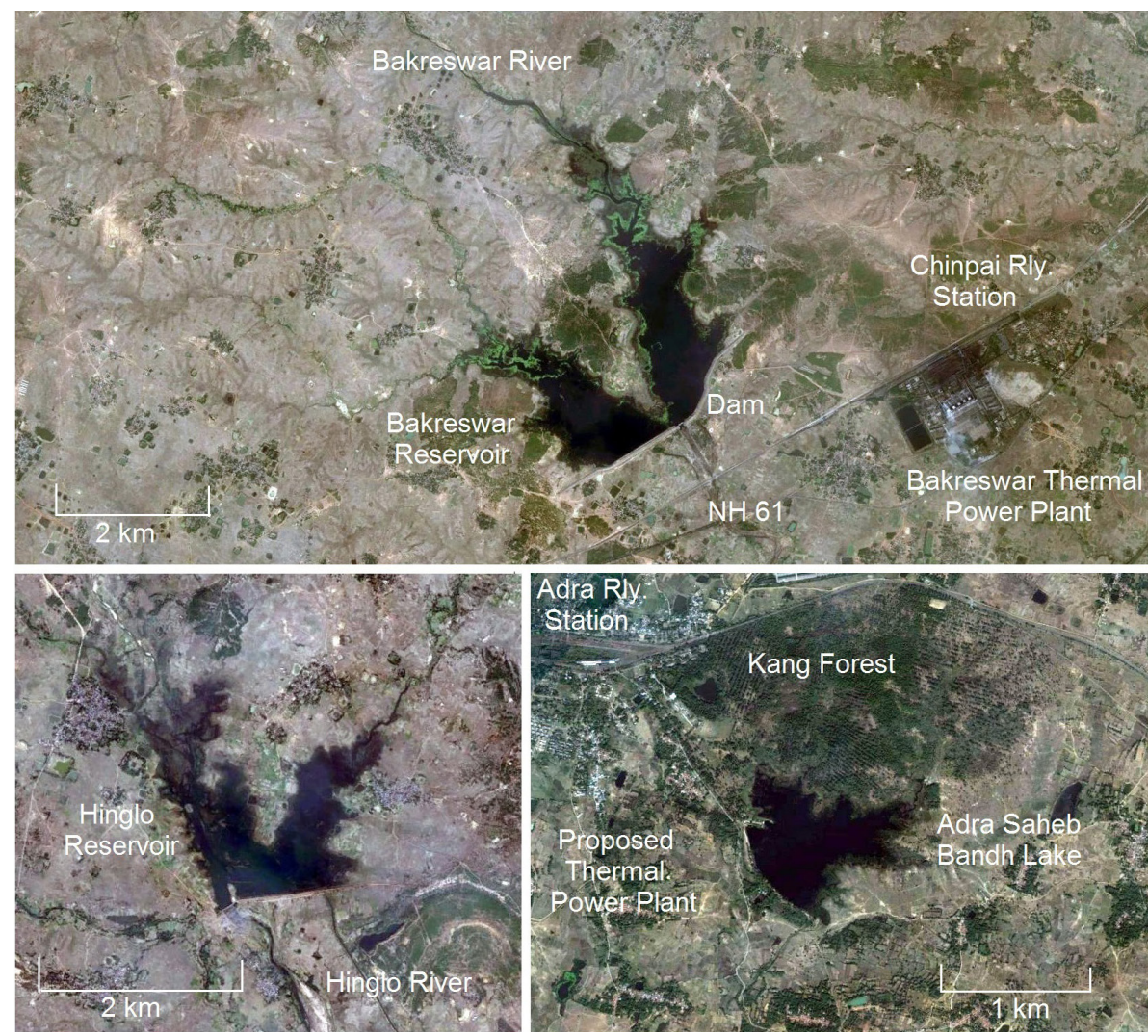

Image 1. Aerial view showing the details of the wetlands and their surroundings. 
errors in waterbird counts and to control for spatial autocorrelation. Prior to these censuses, pilot surveys were made in all the wetlands during the third week of December 1998 (the period when all the migratory waterbirds were present), mainly to (1) familiarise with the waterbird fauna and the habitat features; (2) demarcate wetland boundaries, likely census routes and other important features on maps, (3) set up census routes and vantage points; and (4) prepare a standard sheet for recording the data.

In each wetland, waterbird counts were made on foot and country boat by 10-12 observers employing the same methods as followed by Wetlands International (1997, 2006) and Khan (2010). During each census, counts were begun at $08: 00 \mathrm{hr}$ and continued until the total waterbird count of the entire wetland was completed. The details of the counting efforts in each wetland in each of the census years are presented in Appendix 2.

Since any long-term study of waterbird population trends necessitates bird counts following the same consistent methodology (Wetlands International 2010), each wetland was covered systematically every year since 1998 by slowly walking the same route every year and stopping every $300 \mathrm{~m}$ (i.e., vantage points) to count waterbirds with binoculars (Nikon $8 \times 40$ ) and spotting scopes (20x magnification). Repeated scans were used to obtain a consistent estimate, and to maximise the chances of finding inconspicuous or rare species present in small numbers. Birds were counted one at a time and tally counters were used to speed up the process and minimise errors.

To ensure consistency of coverage from year to year, the route and the vantage points of each observer were recorded using GPS (Garmin ETrex) and strictly followed throughout the study period. The count units allotted to each observer also remained the same in all the 16 census years. Boat surveys were made only in areas inaccessible to ground survey.

From 2003 onwards photographic surveys of all the wetlands have been undertaken to examine the groundand boat-based survey data and potential biases. Such a survey has been regarded as an efficient bird census technique (FAO 2010). This involved producing a set of photographs (Nikon DSLRs attached with 70-200 or $600 \mathrm{~mm}$ lens as required) covering the entire area of each wetland, and the waterbirds were counted later on computers. Photographic surveys were conducted from suitable platforms, which provided unobstructed views of the survey area and at adequate distances that produced images with sufficient resolution to permit species identification and distinguish individual birds even in dense flocks.

\section{Collection of data on waterbird food-bases and other wetland variables}

A list of the important variables relevant to the purpose of this study is presented in Table 1 . Wetlandwise data were collected every year from 1998 to 2013 by 10-12 observers on the next 1-2 days (depending on wetland size) following the completion of the bird census between 08:30 and 17:30 hr (total measurements = 16 years $\times 3$ wetlands $=48$ ).

\section{Wetland area, wetland depth and annual rainfall}

Wetland area was estimated from GPS data, with the help of professional surveyors, on Map Maker Pro 3.5 (www.mapmaker.com) following Khan (2010). Wetland depth was estimated following Taft et al. (2002). We positioned two sampling transects roughly at $45^{\circ}$ angles

Table 1. Major waterbird food-bases and some important variables in three wetlands of southern Bengal, India. The variances of these variables were analysed using repeated measures ANOVA [*significant $\boldsymbol{P}$ values after Bonferroni corrections for two comparisons (for three wetlands; comparison-wise error rate $\mathbf{0 . 0 2 5}$, as well as for 120 comparisons (for 16 years); comparison-wise error rate $\mathbf{0 . 0 0 0 4}$ ].

\begin{tabular}{|l|c|c|c|c|c|}
\hline \multirow{2}{*}{ Wetland variables } & \multirow{2}{*}{ Mean \pm SD } & \multicolumn{2}{|c|}{ Between wetlands } & \multicolumn{2}{|c|}{ Between years } \\
\cline { 3 - 6 } & & $F_{2}$ & $P$ & $F_{15}$ & $P$ \\
\hline Zooplankton abundance $(\mathrm{no} . / \mathrm{ml})$ & $24.02 \pm 1.81$ & 106.7 & $<0.0001^{*}$ & 1.25 & 0.292 \\
\hline Macroinvertebrate abundance $\left(\mathrm{no} . / \mathrm{m}^{2}\right)$ & $18.25 \pm 2.30$ & 168.8 & $<0.0001^{*}$ & 1.42 & 0.200 \\
\hline Fish abundance $\left(\mathrm{no} . / \mathrm{m}^{2}\right)$ & $14.65 \pm 0.81$ & 188.7 & $<0.0001^{*}$ & 1.83 & 0.077 \\
\hline Macrophyte abundance $\left(\mathrm{g} / \mathrm{m}^{2}\right)$ & $32.35 \pm 2.02$ & 204.3 & $<0.0001^{*}$ & 2.05 & 0.046 \\
\hline Dissolved $\mathrm{O}_{2}$ content $(\mathrm{mg} / \mathrm{l})$ & $6.10 \pm 0.47$ & 7.63 & $0.003^{*}$ & 0.82 & 0.650 \\
\hline Annual rainfall $(\mathrm{cm})$ & $14.80 \pm 2.74$ & 0.66 & 0.522 & 3.29 & 0.003 \\
\hline Wetland area $($ hectare) & $415.3 \pm 1.7 .4$ & 1604 & $<0.0001^{*}$ & 1.87 & 0.070 \\
\hline Wetland depth $(\mathrm{m})$ & $3.48 \pm 0.139$ & 550.5 & $<0.0001^{*}$ & 2.68 & 0.010 \\
\hline
\end{tabular}


to the slope (shallow to deep areas) of each wetland. Using a centimetre-marked staff, we measured water at systematically spaced points along these transects, beginning at a random location $0-10 \mathrm{~m}$ from the wetland edge. We obtained at least 25 point samples from each wetland to determine the average water depth with an absolute error of $3 \mathrm{~cm}$. The rainfall data of the wetland areas for all the study years from 1998 to 2013 were obtained from the Regional Meteorological Centre, Kolkata, Sriniketan (Santiniketan) and Purulia, West Bengal.

\section{Waterbird food-bases}

Since, macrophytes (i.e., submerged and emergent vegetation), macroinvertebrates and fish (for the piscivorous and some omnivorous species) constitute the major food-bases of these waterbirds (Crosby \& Chan 2006; BirdLife International 2011) estimates of the waterbird food-bases were restricted to these three variables. The sampling protocol was designed to ensure consistent sampling pressure in all the wetlands throughout the study period. Unless stated otherwise, sampling sites within a wetland were determined along randomly selected sampling transects using computer generated random numbers (for more details see Appendix 2). The minimum distance between two sampling sites was $200 \mathrm{~m}$.

Macrophyte surveys were conducted from small boats, slowly rowing through all shallow water areas that supported aquatic plants. Macrophyte samples were collected using quadrats $(25 \times 25 \mathrm{~cm})$ from vertical core sampling sites along sampling transects. Transects were laid perpendicular to the shoreline, running for a distance of $80 \mathrm{~m}$ from the shore into the deep water. This transect length was fixed since macrophytes were absent in waters deeper than $4 \mathrm{~m}$, presumably because of light limitation (median Secchi depth $=1.9 \mathrm{~m}$ ). Five vertical core sampling sites were established along each transect at points $0,20,40,60$ and $80 \mathrm{~m}$ from the shore, as adopted by Capers et al. (2007). Transect locations were selected to represent site heterogeneity. Eight to 12 transects (40-60 sampling points) were established in each wetland depending on its size (see Appendix 2). To equalise sampling efforts in wetlands of different sizes, one transect was established for each 25ha of the shallow-water (i.e., up to $4 \mathrm{~m}$ deep) area. Each sample was dried separately at $80^{\circ} \mathrm{C}$ for $48 \mathrm{hr}$. The mean biomass was calculated and expressed in $\mathrm{g} / \mathrm{m}^{2}$ and was taken as the macrophyte abundance. The dominant macrophytes were Sedge (Scirpus spp.), Reed (Fragmites sp.), Water Lily (Nymphaea spp.), Pond weeds (Potamogeton spp.),
Water lettuce (Enteromorpha sp.), Water chestnut (Trapa natans), Water thyme (Hydrilla verticillata), Water spinach (Ipomoea aquatica), etc.

Macroinvertebrate samples were collected from small boats using standard $0.5 \mathrm{~mm}$ mesh $\mathrm{D}$-frame dip nets following DiFranco (2006) and Sarkar et al. (2014). Each sweep was made through the water column for a distance of $1 \mathrm{~m}$. Three replicate dip net samples were collected in each inundated plant zone. Each replicate was collected from five locations $20 \mathrm{~m}$ apart along sampling transects (as in macrophyte sampling). Each dip net replicate collection was a composite of sweeps taken at the surface, mid-depth and just above the sediments. Oligochaets (mainly Tubifex and leeches), crustaceans (mainly shrimps and crabs), mites, larval and pupal insects (Chironomidae, Culicidae, Odonata and Ephemeroptera), gastropods and bivalves were the dominant macroinvertebrate fauna.

Fish abundance was estimated using catch-effort method (Johnson 1965) deploying cast nets (mesh size $6 \mathrm{~mm}$; radius $1.5 \mathrm{~m}$; sampling area $2.4 \pm 0.2 \mathrm{~m}^{2}$ ), as used by Sarkar et al. (2014). During each census 30 random deployments (10 deployments each along the edge, midline length and midline breadth of the wetland) were made from country boats and the mean number of fish caught per deployment was used to measure fish density. For the fish abundance, fish collections were reported as number of fish $/ \mathrm{m}^{2}$.

Variances in all the variables were analysed using repeated-measures ANOVA (SPSS; v20). The spatial (i.e., wetland-wise) variances in these variables, excepting annual rainfall, were statistically significant, but the temporal (i.e., year-wise) variance for all the variables yielded insignificant result (Table 1).

\section{Data processing}

Among a total of 48 waterbird species recorded during the course of this study (for checklist see Sinha et al. 2011) 24 were either local migrants or long-distance winter visitors (Table 2), while the others were residential (Grimmett et al. 2011; Sinha et al. 2011). However, 19 common species (i.e., species with a total of $>1000$ individuals recorded over the 16 census years) were considered for this study. The other five species were either vagrants or their abundances were too low to exhibit any discernible trends in their populations or to exert any significant effect on the waterbird community composition (cf. Table 2).

\section{Waterbird abundances and diversity}

The waterbird census data for all the census years 
were processed for diversity estimations with regard to the total number of species (i.e., species richness) and number of individuals (i.e., species abundance) in each wetland, as well as to the Dominance [D = $1-\Sigma\left(p_{i}\right)^{2} ; p_{i}=$ proportion of individuals found in $\mathrm{i}^{\text {th }}$ species], ShannonWeiner diversity $\left[\mathrm{H}^{\prime}=-\mathrm{S} \mathrm{p}_{\mathrm{i}}\left(\ln \mathrm{p}_{\mathrm{i}}\right)\right.$; In = natural $\left.\log \right]$ and Pielou's Equitability $\left[\mathrm{J}^{\prime}=\mathrm{H}^{\prime} / \mathrm{InS}\right.$; where $\mathrm{H}^{\prime}=$ ShannonWeiner diversity and $\mathrm{S}=$ total number of species] using the program PAST (version 2.17) (Hammer et al. 2001). The differences in different diversity components of waterbirds among different wetlands were statistically analysed using two-way analysis of variance (ANOVA). All the results were subjected to Bonferroni corrections for multiple comparisons (i.e., 3 comparisons for 3 wetlands and 120 comparisons for 16 census years).

\section{Waterbird population trends}

Species-wise population trends for each wetland were analysed employing the programme TRIM (Trends and Indices for Monitoring data - Pannekoek \& van Strien 2001) using the bird census data. TRIM analyses time series of counts and produces yearly indices of abundance and trends using Poisson regression. From the modelling options in the TRIM, 'Time Effect Model' was selected for the estimation of the imputed yearly population indices. The population trend of each species was described by this TRIM Imputed index. As summary statistics, overall trends in yearly indices were computed, taking into account their uncertainty. These trends were expressed as multiplicative slopes, i.e., as yearly multiplication factors ( $1=$ stable) and were classified into the following categories according to statistical significance and magnitude (Pannekoek \& van Strien 2001):

a. Strong increase - increase significantly more than $5 \%$ per year and thus the lower limit of the confidence interval of the slope estimate is $>1.05$;

b. Moderate increase - significant increase, but not significantly more than $5 \%$ per year, and thus the lower limit of the confidence interval is $>1.0$ but $<1.05$;

c. Stable - no significant increase or decline, and it is certain that trends are less than $5 \%$ per year; thus the confidence interval encloses 1.00 but the lower limit is $>0.95$ and the upper limit is $<1.05$.

\section{Trends in wetland variables}

Trends in waterbird food-bases and other wetland variables were analysed employing Poisson-based loglinear models (SPSS; Version 20) using the wetland variable data. As in waterbird population trends, time series of estimates and yearly indices of abundance and trends were obtained from these models. These trends were also expressed as multiplicative slopes and were classified into different categories according to statistical significance and magnitude so as to correlate them with the waterbird trends. In addition to the categories used for waterbird population trends, the following two classes were included to explain the trends in wetland variables properly. These additional categories were:

a. Uncertain - no significant increase or decline, but not certain if trends are less than 5\% per year; thus the confidence interval encloses 1.00 but the lower limit is $<0.95$ or the upper limit is $>1.05$;

b. Moderate decline - significant decline, but not significantly more than $5 \%$ per year; thus the upper limit of the confidence interval is $>0.95$ but $<1.00$;

\section{Community analysis}

Community analyses were made on the abundance data of all waterbird species recorded during the study period. For the ordination of waterbird communities, we made use of non-metric multidimensional scaling (nMDS) procedure on the abundance data for all waterbirds grouped by year, using Bray-Curtis dissimilarities. nMDS is the most generally effective ordination method for ecological community data (McCune \& Grace 2002). It iteratively searches for the best positions of $n$ communities on $k$ dimensions (i.e., axes). The ordination presented here shows the relative distance between the waterbird communities in multivariate space: communities that are more similar in species composition appear closer together on the ordination plot than those are dissimilar (Ludwig \& Reynolds 1988; McCune \& Grace 2002). The grouping by year allowed a determination of temporal variations in community structure of the wetland.

A multi-response permutation procedure (MRPP) was performed on the data using the Bray-Curtis dissimilarities as the distance measure, wetlands as the grouping variable and census years as the blocking variable. MRPP is a nonparametric procedure highly recommended for ecological data (McCune \& Grace 2002). The resultant $T$ statistic describes the separation between the groups (wetlands here), with a more negative value of $T$ indicating a stronger separation, while the $A$-statistic, describes within-group (i.e., withinwetland) homogeneity compared to random expectation (higher values indicate higher homogeneity). We used this test to determine whether the waterbird communities differed statistically among the wetlands, as well as among the census years.

In order to identify the species that were important 
in structuring the waterbird community, Blocked Indicator Species Analysis (ISA) was performed (Dufrene \& Legendre 1997) for the common species (species with a total of $>5000$ individuals recorded over the 16 census years) with samples grouped by wetland and blocked by census years. ISA identifies species associated with groups (i.e., wetlands) by calculating an indicator value (ranging between 0 and 100), which reflects both frequency and abundance of species in defined groups. Significance of indicator values was assessed using Monte Carlo simulations with 4999 permutations.

All these multivariate analyses were performed using PC-ORD, Version 6.0 (McCune \& Mefford 2006), and standard procedures outlined in McCune \& Grace (2002).

\section{RESULTS}

\section{Waterbird abundances and diversity}

A total of 442,345 waterbirds belonging to 24 species were recorded during the course of this study (Table 2). There were significant spatial (i.e., between wetlands) variances but insignificant temporal (i.e., between years) variances in the important aspects of waterbird diversity (Table 3). Bakreswar Reservoir exhibited highest species (mean number 11,972), while Adra Saheb Bandh Lake was lowest (mean number 8,626 ) in species abundances. The total number of waterbirds and their mean number for each individual wetland (Fig. 2) showed that, although there were year-wise variations, Bakreswar Reservoir exhibited an increasing trend in waterbird abundance throughout the study period, while Adra Saheb Bandh maintained almost a stable state. In the Hinglo Reservoir, the total number of waterbirds started increasing from 2009 after maintaining an almost stable state during the period from 2004 to 2008 . Shannon-Wiener diversity in Bakreswar (2.129) and Hinglo (2.276) Reservoirs was considerably higher than that of Adra Saheb Bandh Lake (1.565). The dominance was negligible in the first two wetlands and low in Adra Saheb Bandh Lake. The species evenness (i.e., equitability) was high in all the three wetlands although Adra Saheb Bandh Lake yielded a lower value than those of the other two wetlands (cf. Table 3).

\section{Waterbird population trends}

Although a total of 24 migratory waterbirds recorded during the course of this study, 19 species were considered for population trend analysis (see methods; for the excluded species see Table 2). The results (Fig.
3) indicated a significant increase (compared to 1998 population sizes) for 14 waterbirds both in Bakreswar and Hinglo Reservoirs, while the others remained stable throughout the study period. In Bakreswar Reservoir, four species exhibited notable increases during the period from 1998 to 2016 . They included Greylag Goose (289.47\% increase), Bar-headed Goose (2310.53\% increase), Tufted Duck (582.68\% increase) and Eurasian Coot (310.94\% increase). Lesser Whistling Duck (185.89\% increase) and Red-crested Pochard (191.93\% increase) also showed considerable increases during this period. In Hinglo Reservoir, however, only Red-crested Pochard exhibited a remarkable increase by 270.23\% during 1998-2016, while most other species either increased moderately or remained stable. In sharp contrast to these trends, all the waterbird species maintained stable states in Adra Saheb Bandh Lake, excepting Ferruginous Duck and Eurasian Coot, which increased moderately (Fig. 3).

These patterns of waterbird population trends were also reflected in analyses of feeding guilds (Fig. 4; for guild memberships see Table 2). For instance, a $278.3 \%$ increase in the carnivorous waterbirds in Bakreswar Reservoir can well be the reflection of noticeable increases in Little Grebe (295.68\% increase) and Great Crested Grebe (by $223.68 \%$ increase) in this wetland. Similarly, overall increases by $47.72 \%, 69.94 \%$ and $64.51 \%$ in the herbivorous, omnivorous and carnivorous waterbirds respectively in these wetlands between 1998 and 2013 also showed moderate increases in all the feeding guilds (Wald $\chi_{14}^{2}=764.25, P<0.0001$; $\chi_{14}^{2}=1093.97, P<0.0001 ; \chi_{14}^{2}=70.07, P<0.0001$ for herbivores, omnivores and carnivores respectively).

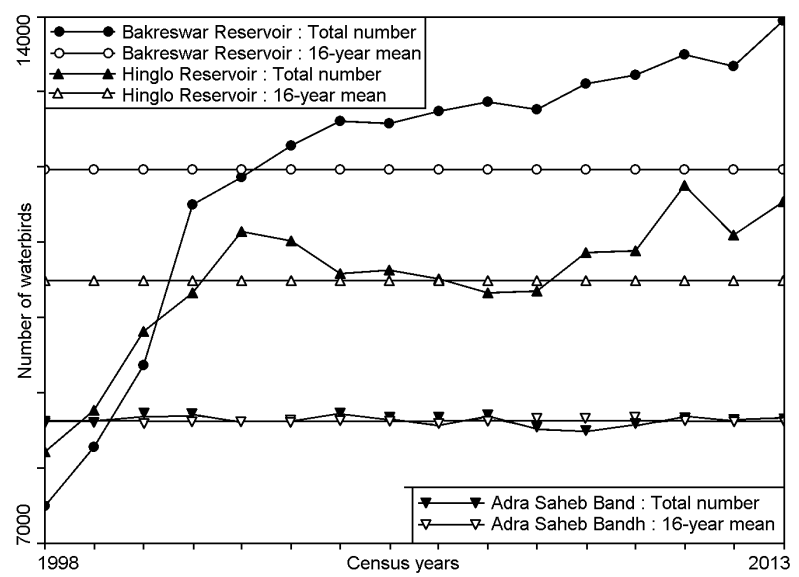

Figure 2. Year-wise total number and 16-year mean number of waterbirds in three wetlands of southern Bengal. 
Table 2. List of waterbirds encountered and counted during 1998-2013 along with their occurrence in different wetlands, abundance and residing status ( $\mathrm{R}=$ Resident; $\mathrm{LM}=$ Local migrant; $\mathrm{WM}=$ Winter migrant). * Species excluded from population trend and community analyses.

\begin{tabular}{|c|c|c|c|}
\hline Waterbird Species & Code & No. of birds ${ }^{1}$ & Occurrence $^{2}$ \\
\hline 1. Little Grebe (Tachybaptus ruficollis) (R/LM) & LGR & 15334 & All \\
\hline 2. Great Crested Grebe (Podiceps cristatus) (WM) & GCG & 3223 & All \\
\hline 3. Greylag Goose (Anser anser) (WM) & GLG & 7601 & 1,2 \\
\hline 4. Bar-headed Goose (Anser indicus) (WM) & BHG & 22999 & 1,2 \\
\hline 5. Lesser Whistling Duck (Dendrocygna javanica) (R/LM) & LWD & 113911 & All \\
\hline 6. Fulvous Whistling Duck (Dendrocygna bicolor) (R/LM) & FWD & 10261 & All \\
\hline 7. Ruddy Shelduck (Tadorna ferruginea) (WM) & RSD & 14388 & 1,2 \\
\hline 8. Northern Pintail (Anas acuta) (WM) & PIN & 20371 & All \\
\hline 9. Common Teal (Anas crecca) (WM) & CTL & 3922 & All \\
\hline 10. Gadwall (Anas strepera) (WM) & GAD & 20372 & All \\
\hline 11. Eurasian Wigeon (Anas penelope) (WM) & WIG & 16885 & All \\
\hline 12. Garganey (Anas querquedula) (WM) & GAR & 1079 & 1,2 \\
\hline 13. Northern Shoveler (Anas clypeata) (WM) & $\mathrm{SHO}$ & 4492 & 1,2 \\
\hline 14. Cotton Pygmy Goose (Nettapus coromandelianus) (R/LM) & CPG & 30794 & All \\
\hline 15. Red-crested Pochard (Netta rufina) (WM) & RCP & 66078 & All \\
\hline 16. Common Pochard (Aythya ferina) (WM) & $\mathrm{CPO}$ & 3435 & 3 \\
\hline 17. Ferruginous Duck (Aythya nyroca) (WM) & FDK & 5603 & All \\
\hline 18. Tufted Duck (Aythya fuligula) (WM) & TDK & 46149 & All \\
\hline 19. Eurasian Coot (Fulica atra) (WM)** & ECT & 33391 & All \\
\hline 20. Grey-headed Lapwing (Vanellus cinereus) (WM)* & GHL & 653 & 1,2 \\
\hline 21. Common Redshank (Tringa totanus) (WM)* & CRS & 112 & 1,2 \\
\hline 22. Green Sandpiper (Tringa ochropus) (WM)* & GSP & 487 & 1,2 \\
\hline 23. Wood Sandpiper (Tringa glareola) (WM)* & WSP & 731 & 1,2 \\
\hline 24. Common Sandpiper (Actitis hypoleucos) (WM)* & CSP & 74 & 1,2 \\
\hline
\end{tabular}

${ }^{1}$ Total number of waterbirds recorded in three wetlands during the period between 1998 and 2013.

${ }^{2}$ All= All three wetlands; $1=$ Bakreswar Reservoir; $2=$ Hinglo Reservoir; 3= Adra Saheb Bandh Lake

** Despite the fact that a few birds come over summer annually, there is no evidence of local breeding although the species breed elsewhere in India (up to $2500 \mathrm{~m}$ in the Himalayas) (Ali \& Ripley 1978). The wintering population, presumably come from central and northern Asia. (www.birds. iitk.ac.in/wiki/eurasian-coot).

\section{Trends in wetland variables}

The analysis of the trends in wetland variables (Fig. 3) indicated a significant increase in macrophyte, macroinvertebrate and fish abundances in Bakreswar Reservoirs, while the other two wetlands exhibited stable states for these three food-bases of the waterbirds. The wetland area and depth did not show any noticeable change throughout the study period, but the amount of rainfall declined significantly (Fig. 3).

\section{Waterbird community structure}

nMDS ordination of the waterbird species abundance data yielded a two-dimensional solution (Fig. 5). The two nMDS axes explained most of the variance (Axis 1= $72.6 \%$; Axis $2=26.2 \%$ ). Axis 1 separated the waterbird communities of Adra Saheb Bandh Lake from Hinglo Reservoir. The waterbird communities of Bakreswar and Hinglo Reservoirs were distinguished from that of Adra Saheb Bandh Lake on the axis 2.

The analysis suggested that both spatial and temporal gradients existed in the waterbird community structure of these wetlands. Two distinct clusters were observed in the ordination plot (Fig. 5). The first cluster was formed by the waterbird communities of Bakreswar and Hinglo Reservoirs. The waterbird communities of Adra Saheb Bandh Lake made up the second cluster. The waterbird community structure exhibited temporal variations within each of these wetlands, with a maximum in Bakreswar Reservoir and minimum in Adra Saheb Bandh Lake.This analysis also suggested that the 

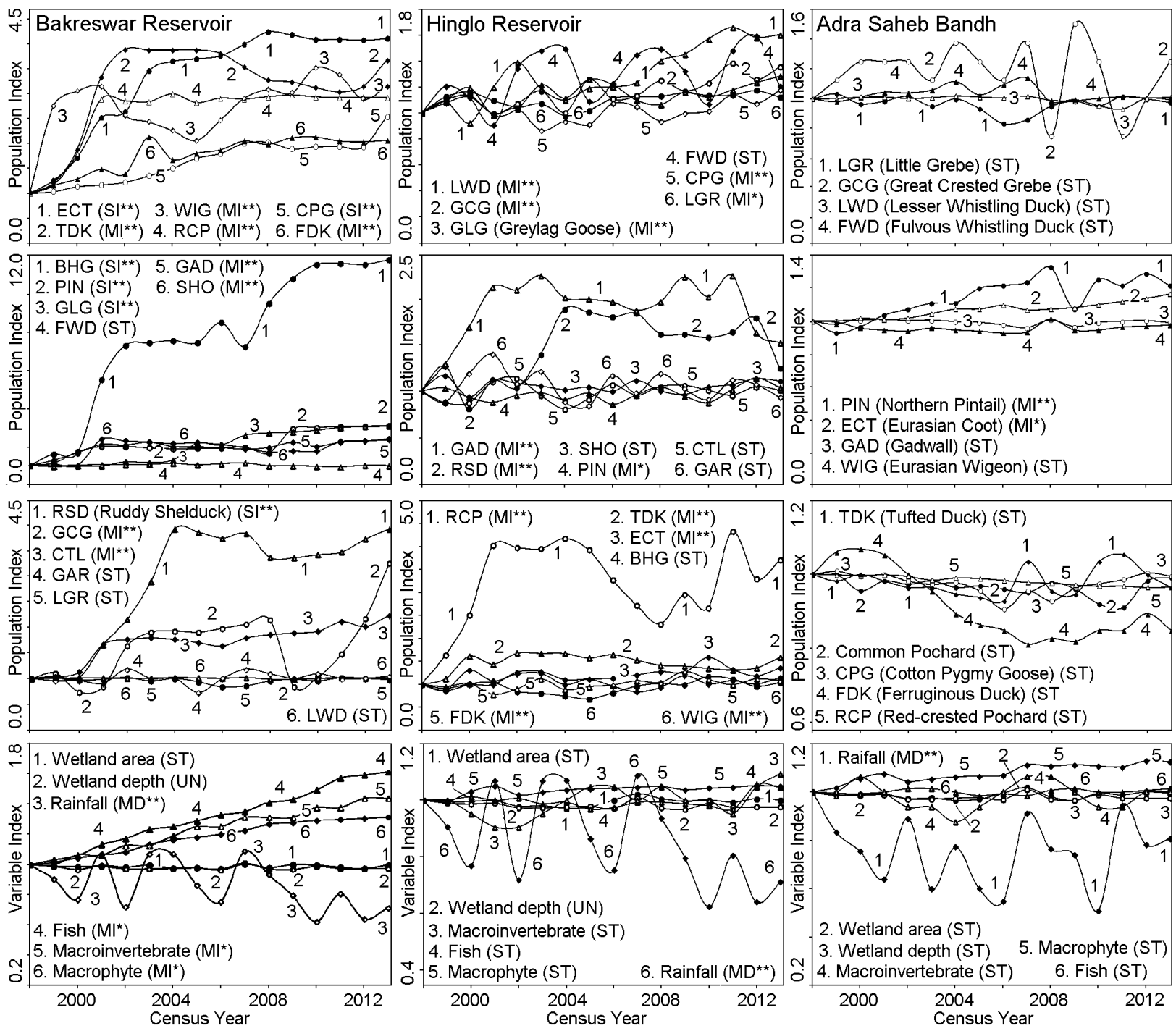

Figure 3. Trends in waterbird populations and some of their important habitat variables in three wetlands of southern Bengal during the period between 1998 and 2013 (MI = Moderate increase; SI = Strong increase; ST = Stable; UN = Uncertain; MD = Moderate decline). Starting year was 1998 for all species (population index $=1.00$ ) and all variables (variable index $=1.00$ ). ). Indices $>1.00$ indicate increases and $<1.00$ indicate declines; * $P<0.05 ;{ }^{* *} P<0.01$ (see 'Methods').

variation in community structure between wetlands was greater than variation in community structure between years within each of these three wetlands.

The low negative value of $T$ (i.e., -16.503), resulted from MRPP, confirmed that the waterbird community structure did not differ substantially between these wetlands. In contrast, a large value of ' $A$ ' statistic (i.e., $A=0.672, P=<0.00001$ ) clearly reflected the distinct qualities of species composition in each wetland and high homogeneity among the communities within any given wetland in these 16 years.

The results of the indicator species analysis revealed that species with statistically significant indicator values were present in all the wetlands (Table 4). Hinglo
Reservoir had 15 significant indicators indicating that it was richer in species than other wetlands and supported a more unique species composition. Among these species were the Great Crested Grebe Podiceps cristatus, Bar-headed Goose Anser indicus, Northern Pintail Anas acuta, Ruddy Shelduck Tadorna ferruginea, Common Teal Anas crecca, Eurasian Wigeon Anas penelope, Redcrested Pochard Netta rufina and Tufted Duck Aythya fuligula. All these species were winter visitors from the northern areas of Europe and Eurasia, except the Tufted Duck, which travelled from Europe and western Asia (Clements 2007).

At least some members of Bar-headed Goose recorded during this study migrated from Mongolia. 
Table 3. Different components of waterbird diversity in three wetlands for the period between 1998 and 2013 . The variances of these components were analysed using two-way ANOVA [ ${ }^{*}$ significant $\boldsymbol{P}$ values after Bonferroni corrections for three comparisons (for 3 wetlands; comparison-wise error rate $\mathbf{0 . 0 1 7}$, as well as for 120 comparisons (for 16 years); comparison-wise error rate 0.0004 ].

\begin{tabular}{|c|c|c|c|c|c|c|}
\hline & \multicolumn{2}{|c|}{ Bakreswar Reservoir } & \multicolumn{2}{|c|}{ Hinglo Reservoir } & \multicolumn{2}{|c|}{ Adra Saheb Bandh } \\
\hline & Range & Mean $\pm S D$ & Range & Mean $\pm S D$ & Range & Mean $\pm S D$ \\
\hline \multirow[t]{2}{*}{ Taxa } & $17-18$ & $17.94 \pm 0.25$ & 18 (all) & $18 \pm 0$ & 13 (all) & $13 \pm 0$ \\
\hline & \multicolumn{6}{|c|}{ Spatial (between wetlands) $F_{2}=6321.0, P<0.0001^{*} ;$ Temporal (between years) $F_{15}=1.00, P=0.480$} \\
\hline \multirow[t]{2}{*}{ Individuals } & 7489-13958 & $11972 \pm 1910.8$ & $8216-11765$ & $10492.4 \pm 924.03$ & $8488-8716$ & $8626.6 \pm 58.73$ \\
\hline & \multicolumn{6}{|c|}{ Spatial (between wetlands) $F_{2}=46.21, P<0.0001^{*}$; Temporal (between years) $F_{15}=2.63, P=0.012$} \\
\hline \multirow[t]{2}{*}{ Dominance_D } & $0.153-0.374$ & $0.200 \pm 0.063$ & $0.085-0.096$ & $0.091 \pm 0.003$ & $0.330-0.336$ & $0.333 \pm 0.002$ \\
\hline & \multicolumn{6}{|c|}{ Spatial (between wetlands) $F_{2}=171.69, P<0.0001^{*} ;$ Temporal (between years) $F_{15}=0.91, P=0.564$} \\
\hline \multirow[t]{2}{*}{ Shannon_H' } & $1.667-2.278$ & $2.129 \pm 0.171$ & $2.537-2.620$ & $2.276 \pm 0.023$ & $1.554-1.579$ & $1.565 \pm 0.007$ \\
\hline & \multicolumn{6}{|c|}{ Spatial (between wetlands) $F_{2}=389.97, P<0.0001^{*} ;$ Temporal (between years) $F_{15}=0.84, P=0.627$} \\
\hline Equitability_J' & $0.588-0.788$ & $0.737 \pm 0.057$ & $0.878-0.906$ & $0.891 \pm 0.008$ & $0.606-0.616$ & $0.610 \pm 0.003$ \\
\hline
\end{tabular}

Table 4. List of species for which a total of at least $\mathbf{5 0 0 0}$ individuals were counted over the 16 census periods and that were significant indicators for the three wetlands of southern Bengal.

\begin{tabular}{|l|c|c|l|}
\hline Species & $\begin{array}{c}\text { Indicator } \\
\text { Value }\end{array}$ & $\boldsymbol{p}^{*}$ & Wetland \\
\hline Little Grebe & 50.5 & 0.0002 & Hinglo Reservoir \\
\hline Great Crested Grebe & 66.1 & 0.0002 & Hinglo Reservoir \\
\hline Greylag Goose & 61.5 & 0.0002 & Hinglo Reservoir \\
\hline Bar-headed Goose & 61.4 & 0.0002 & Hinglo Reservoir \\
\hline Lesser Whistling Duck & 63.9 & 0.0002 & \begin{tabular}{l} 
Adra Saheb Bandh \\
\hline Fulvous Whistling Duck
\end{tabular} \\
\hline 35.5 & 0.0138 & Bakreswar Reservoir \\
\hline Ruddy Shelduck & 53.0 & 0.0010 & Hinglo Reservoir \\
\hline Northern Pintail & 61.8 & 0.0002 & Hinglo Reservoir \\
\hline Common Teal & 58.4 & 0.0002 & Hinglo Reservoir \\
\hline Gadwall & 36.7 & 0.0006 & $\begin{array}{l}\text { Adra Saheb Bandh } \\
\text { Lake }\end{array}$ \\
\hline Eurasian Wigeon & 43.8 & 0.0026 & Hinglo Reservoir \\
\hline Garganey & 66.9 & 0.0002 & Hinglo Reservoir \\
\hline Northern Shoveler & 58.4 & 0.0002 & Hinglo Reservoir \\
\hline Cotton Pygmy Goose & 44.8 & 0.0002 & Hinglo Reservoir \\
\hline Red-crested Pochard & 48.7 & 0.0002 & Hinglo Reservoir \\
\hline Common Pochard & 100.0 & 0.0002 & Hinglo Reservoir \\
\hline Tufted Duck & 52.2 & 0.0012 & Hinglo Reservoir \\
\hline Eurasian Coot & 48.9 & 0.0002 & Hinglo Reservoir \\
\hline
\end{tabular}

*The $p$ value is the proportion of random trials in which the indicator value was equal to or greater than the observed value. The name given for each species is the wetland for which the species acts as an indicator.

The 2011 and 2012 censuses each on January 25 at Bakreswar Reservoir led to the sightings of two individuals (a male and a female respectively) with orange-coloured collars that had the number $3 \mathrm{~T}$ (see

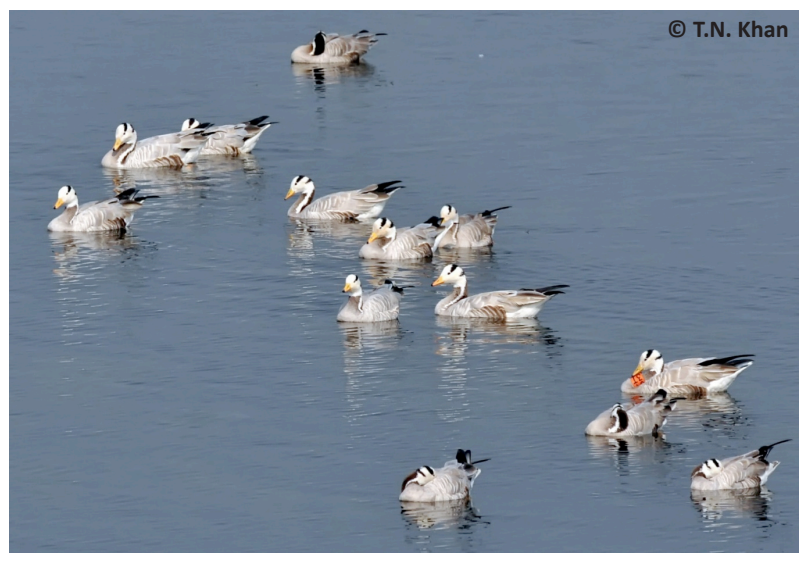

Image 2. The adult male Bar-headed Goose with orange-coloured collar that had the number 3T imprinted on the neck, which was tagged at Tsengel Nuur Lake in Mongolia in May 2009. The bird was photographed at Bakreswar Reservoir on January 25, 2011.

Image 2) and R5 respectively imprinted on them. On sharing this information with various bird banding groups and institutions, it was confirmed by Dr. Robert Thomson of Wildlife Conservation Society that these birds had been collared at Tsengel Nuur Lake $\left(49.7662^{\circ} \mathrm{N}\right.$ \& $101.0126^{\circ} \mathrm{E}$ ) in Huvsgul province and Sharga Nuur Lake respectively in Bulgan province, Mongolia $\left(48.9436^{\circ} \mathrm{N}\right.$ \& $101.9703^{\circ} \mathrm{E}$ ) in July 2009. Many Bar-headed Geese, breeding in Mongolia, are known to fly over the Himalaya during migration and spend the winter in central and northeastern India (Takekawa et al. 2009; Hawkes et al. 2011; Zhang et al. 2011). This winter visitor, however, was restricted to a few wetlands of Birbhum District in southwestern Bengal (Sinha et al. 2011).

Two species acted as significant indicators (see 

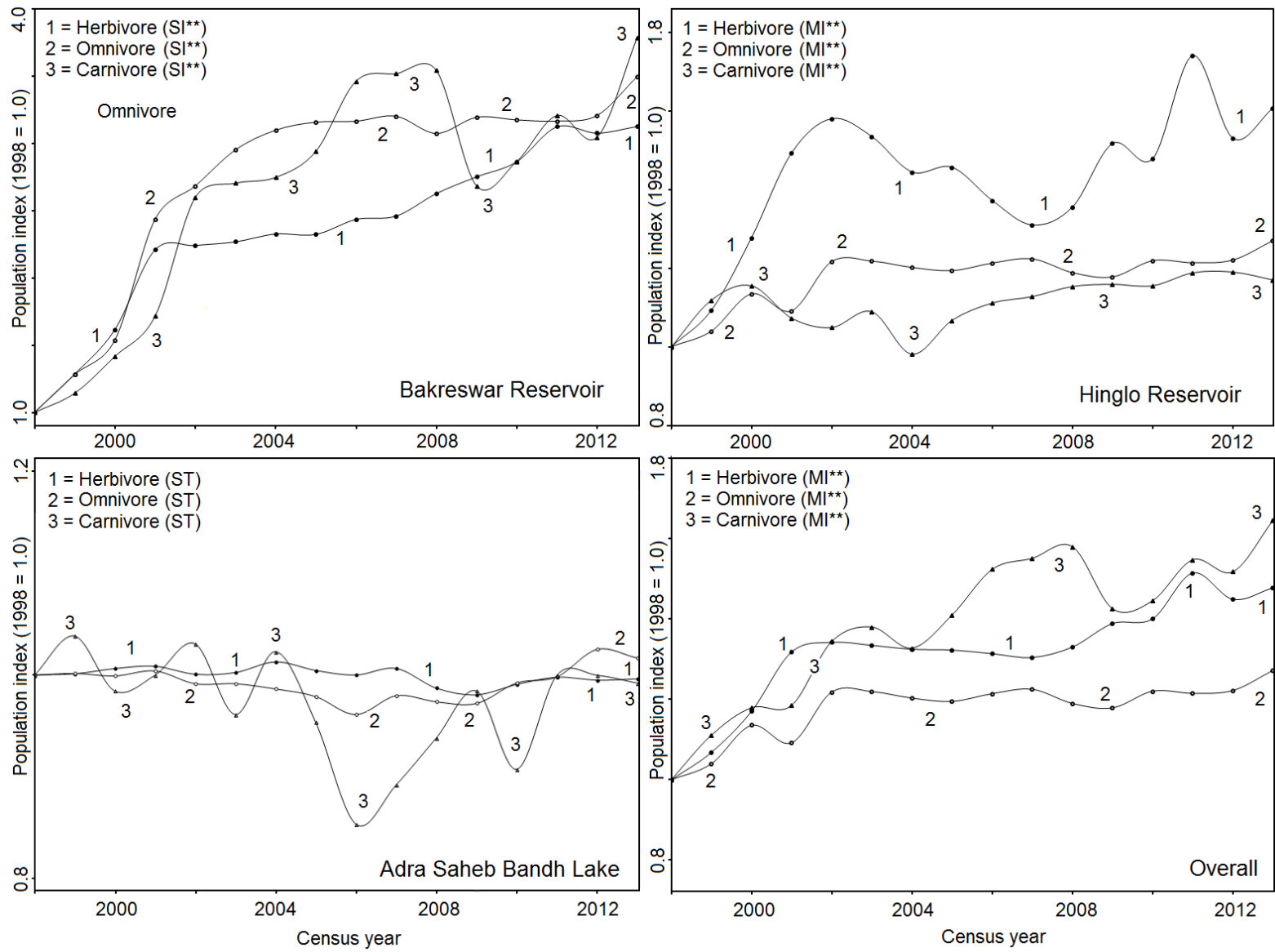

Figure 4. Trends in different waterbird feeding guilds in three wetlands of southern Bengal during the period between 1998 and 2013 (MI = Moderate increase; $\mathrm{SI}=$ Strong increase; $\mathrm{ST}=$ Stable). Starting year was 1998 for all species (population index $=1.00$ ). Population indices $>1.00$ indicate increases; $* * P<0.01$ (see 'Methods').

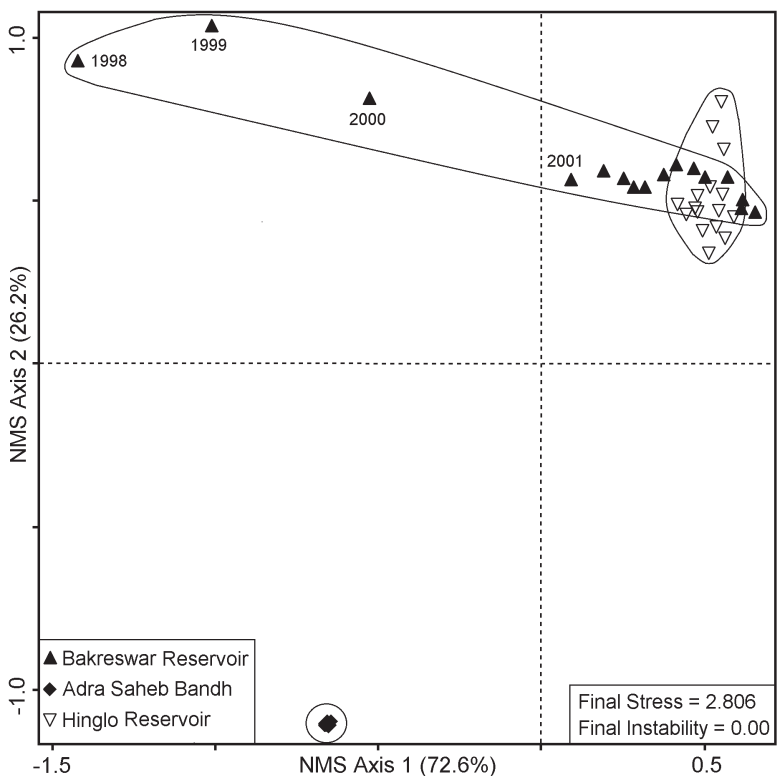

Figure 5.nMDS ordination plot of Bray-Curtis dissimilarities for migratory waterbird species within each wetland in each year $(n=3$ $x \mathbf{1 6}=\mathbf{4 8}$ wetland-years). Percentages shown on axes represent the amount of variance explained by that axis.
Methods: Community Analysis) for the waterbird communities of Adra Saheb Bandh Lake; revealing a much less unique species composition than that of Hinglo Reservoir. They were Lesser Whistling Duck Dendrocygna javanica and Eurasian Wigeon Anas penelope, the latter being a winter visitor from the northern areas of Europe and Eurasia (Clements 2007). Only one species (Ruddy Shelduck, Tadorna ferruginea) acted as a significant indicator for the waterbird communities of Bakreswar Reservoir signifying that it was poor in species composition.

\section{DISCUSSION AND CONCLUSIONS}

Our study indicated stable or increasing waterbird trends in these wetlands in accordance with stable or increasing states of their major food-bases, which might indicate a positive relationship between these two sets of variables. But, relations between habitat characteristics 
and waterbird abundances are difficult to interpret because different factors often act simultaneously, confounding the effects of individual ones (Petit \& Petit 1996; Chalfoun \& Martin 2007), as well as because all species frequent the wetlands not only for food. Many come for rest and shelter. Moreover, the correlations between waterbirds and the wetland variables may be mere reflections of some critical habitat features, often correlated with food-bases, which are not readily measured (Terborgh 1985). Therefore, we are not in a position to single out any individual factor responsible for the observed increases in waterbird populations. However, rainfall, wetland area, wetland depth and major waterbird food-bases have been suggested as the most important factors in this regard (Bartodziej \& Weymouth 1995; Marra et al. 1998; Taft \& Haig 2003; Bolduc \& Afton 2004; Studds \& Marra 2007). The decreasing trend in the amount of rainfall during the course of this study might suggest that this particular factor did not apparently have any significant effect on the observed waterbird population trends. Therefore, observed waterbird trends in these wetlands might be attributed to the relatively static distribution of some key resources, such as the wetland area and shallow waters providing adequate foraging ground and stable or increasing food-bases over the 16-year timeframe of this study. The less temporal variation in the waterbird community composition (MRPP results) might well support such a situation. The increasing waterbird trends in accordance with increasing trends in their major food-bases, especially in Bakreswar Reservoir, might suggest a more positive role of the major foodbases in this regard than the other variables.

On the other hand, consistent increase in the abundances of waterbirds might well have been associated with the creation of Bakreswar Reservoir for the Thermal Power Plant and consequent congregation of waterbirds due to the ecological succession. These increasing waterbird trends might well have been correlated with the increasing trends in their major foodbases (i.e., Macrophytes, macroinvertebrates and fish), especially in the case where wetland area and depth remained stable and the amount of rainfall declined (Fig. 3). In contrast, Hinglo Reservoir had a longer time to establish itself as an important waterbird abode. The stronger temporal gradients observed in Bakreswar Reservoir during the period from 1998 to 2001 than during 2002-2013 (Fig. 4) might well support this possibility, indicating that the waterbird communities were gradually approaching temporal stability with the progress of time. However, migratory waterbirds are opportunistic and adapt to utilise various habitat types during migration and colonisation. The receding water level during winter could have exposed new shallow areas, which provided suitable feeding habitats for both herbivorous and carnivorous bird species. The studies on the arrival, assemblage and departure of the migratory waterbirds in the present study area by Hazra et al. $(2012,2014)$ and (Hazra 2015) suggest that the increase in waterbird numbers due to the arrival of passage during return migration or due to early departure was negligible in these wetlands. None the less, the increasing waterbird population trends in Bakreswar and Hinglo reservoirs might suggest that they would require more time to attain temporal stability so far as their waterbird communities are concerned. Such speculation may further be substantiated by the temporally stable states of the waterbird populations and their community structure prevailing at Adra Saheb Bandh Lake (figs. 3 \& $5)$, which had the opportunity to avail sufficient time to attain its culmination, exhibiting almost stable waterbird communities. Soulliere \& Monfils (1996) obtained similar results from their study on a constructed wetland complex in Michigan. Occurrence of flourishing or stable waterbird communities in these wetlands might well be attributed to the adequate size of food-bases of different species, especially reed and sedge, to cater to more and more waterbirds (Sinha et al. 2011). In many wetlands, the highest species richness and density of waterbirds occur in reed beds (Hattori \& Mae 2001). Moreover, many waterbirds, especially Ruddy Shelduck and Greylag Goose, feed on both the reed and sedge in southwestern Bengal (Maiti et al. 2010).

Adequate protection of Bakreswar Reservoir rendered by the West Bengal State Electricity Board, proper care rendered by Hinglo Dam authority and local people and adequate support rendered by the Railways and Municipal authorities, NGOs and local nature lovers at Adra Saheb Bandh Lake might also have played positive roles in making these wetlands flourishing waterbird abodes. Waterbirds usually avoid areas with extensive disturbance and choose roosting or foraging sites with fewer disturbances (Peters \& Otis 2007) and generally prefer the wetlands with features that maximise the abundance and accessibility of their foods (Taft \& Haig 2003).

Therefore, our findings show that the observed increases in waterbirds was associated with the addition of Bakreswar and Hinglo Reservoirs in the wetland chain of the region, expanding the amount of habitat available for the waterbirds. Such an increase in waterbirds in response to habitat expansions has been a widespread 
phenomenon in different parts of the world (Fasola \& Ruiz 1996; Czech \& Parsons 2002; Rendon et al. 2008). However, since wetland vegetation and faunal composition have a positive influence on waterbird abundance and diversity (Bellrose 1980; Helmers 1992), a newly constructed wetland obviously requires some time to accumulate the required flora and fauna (i.e., resources for the waterbirds) so that it can support a rich variety of waterbirds in sufficient numbers. This might have constituted one of the important causes of lower waterbird diversity and abundances observed during the earlier phases of the life of Bakreswar Reservoir. Therefore, it failed to support adequate numbers of waterbirds in that period. However, with the passage of time, along with the accumulation of required foodbases for these waterbirds (especially reed and sedge), they began to arrive in large numbers (Sinha et al. 2012). The consistent increases in all the waterbird feeding guilds might well indicate that Bakreswar Reservoir has been flourishing at a fast rate (Fig. 4).

The processes governing waterbird abundance and diversity are not yet well understood, which would certainly limit the options for implementing waterbird management strategies. However, these three wetlands have already shown their potential to serve as ideal waterbird abodes. The emergence of such wetlands would certainly make a notable change in the reigning scenario of overall wetland deterioration and destruction along with the loss of aquatic biodiversity. Therefore, these wetlands may well serve as ideal models to the conservationists and decision makers for adopting and implementing proper conservation measures for the wetlands along with their valued denizens. At the present state, all we need to do is to keep them undisturbed and allow them to follow their own course by implementing monitoring programmes on a long-term basis. They have already proved their potential to emerge as some of the richest waterbird abodes in northeastern India.

\section{REFERENCES}

Ali, S. \& S.D. Ripley (1978). Handbook of the birds of India and Pakistan together with those of Bangladesh, Nepal, Bhutan and Sri Lanka. Divers to hawks. Vol. 1. 2nd edition. Delhi (Sponsored by Bombay Natural History Society), Oxford University Press.

Bartodziej, W. \& G. Weymouth (1995). Waterbird abundance and activity on water-Hyacinth and Egeria in the St-Marks River, Florida. Journal of Aquatic Plant Management. 33: 19-22.

Bellrose, F.C. (1980). Ducks, Geese and Swans of North America. Stackpole Books, Harrisburg, PA, 544pp.

BirdLife International (2011). IUCN Red List for Birds. Downloaded from http://www.birdlife.org on 19/03/2011.

Crosby, M.J. \& S.S. Chan (2006). Threatened waterbird species in eastern and southern Asia and actions needed for their conservation, pp. 332-338. In: Boere, G.C., C.A. Galbarith \& D.A. Stround (eds.).Waterbirds Around the World. The Stationery Office, Edinburgh.

Bolduc, F. \& A.D. Afton (2004). Relationships between wintering waterbirds and invertebrates, sediments and hydrology of coastal marsh ponds. Waterbirds 27: 333-341; http://dx.doi. org/10.1675/1524-4695(2004)027[0333:RBWWAI]2.0.CO;2

Capers, R.S., R. Selsky, G.J. Bugbee \& J.C. White (2007). Aquatic plant community invasibility and scale-dependent patterns in native and invasive species richness. Ecology 88: 3135-3143; http://dx.doi. org/10.1890/06-1911.1

Chalfoun, A.D. \& T.E. Martin (2007). Assessment of habitat preferences and quality depend on spatial scale and metrics of fitness. Journal of Applied Ecology 44: 983-992; http://dx.doi.org/10.1111/j.13652664.2007.01352.x

Clements, J. (2007). The Clements Checklist of the Birds of The World. Cornell University Press, Ithaca, 864pp.

Czech, H.A. \& K.C. Parsons (2002). Agricultural Wetlands and Waterbirds: A Review. Waterbirds 25(suppl. 2): 56-65.

Day, J.H. \& M.A. Colwell (1998). Water communities in rice fields subjected to different post-harvest treatments. Colonial Waterbirds 2: 185-197; http://dx.doi.org/10.2307/1521905

DiFranco, J. (2006). Protocols for sampling aquatic macroinvertebrates in freshwater wetlands. Maine Department of Environmental Protection No. DEPLW0640

Dufrene, M. \& P. Legendre (1997). Species assemblages and indicator species: The need for a flexible asymmetrical approach. Ecological Monograph 67: 345-366; http://dx.doi.org/10.1890/00129615(1997)067[0345:SAAIST]2.0.CO;2

Elphick, C.S. (2000). Functional equivalency between rice fields and seminatural wetlands habitats. Conservation Biology 14: 181-191; http://dx.doi.org/10.1046/j.1523-1739.2000.98314.x

Elphick, C.S. \& L.W. Oring (1998). Winter management of California rice fields for waterbirds. Journal of Applied Ecology 35: 95-108; http:// dx.doi.org/10.1046/j.1365-2664.1998.00274.x

FAO (2010). Wild Birds and Avian Influenza: an introduction to applied field research and disease sampling techniques. Chapter 6. Avian surveys and monitoring, 85-94pp.

Fasola, M. \& X. Ruiz (1996). The value of rice fields as substitutes for natural wetlands for waterbirds in the mediterranean region. Colonial Waterbirds 19: 122-128; http://dx.doi.org/10.2307/1521955

Grimmett, R., C. Inskipp \& T. Inskipp (2011). Birds of the Indian Subcontinent. Oxford University Press, London, 528pp.

Hammer, Ø., D.A.T. Harper \& P.D. Ryan (2001). PAST: Paleontological Statistics Software Package for Education and Data Analysis. Palaeontologia Electronica 4(1): art. 4: 9pp. Downloaded on 11 May 2010.

Hattori, A. \& S. Mae (2001). Habitat use and diversity of waterbirds in a coastal lagoon around Lake Biwa, Japan. Ecological Research 16: 543-553; http://dx.doi.org/10.1046/j.1440-1703.2001.00416.x

Hawkes, L.A., S. Balachandran, N. Batbayar, P.J. Butler, P.B. Frappell, W.K. Milsom, N. Tseveenmyadag, S.H. Newman, G.R. Scott, P. Sathiyaselvam, J.Y. Takekawa, M. Wikelski \& C.M. Bishop (2011). The trans Himalayan flights of Bar-headed Geese (Anser indicus). PNAS 108: 9516-9519; http://dx.doi.org/10.1073/ pnas. 1017295108

Hazra, P. (2015). Photoperiodic Effects and Temperature Impacts in Migratory Waterbirds at some Tropical Wetlands of South Bengal, India. PhD Thesis, University of Calcutta, May 2015, 108pp.

Hazra, P., A. Sinha, P. Mondal \& T.N. Khan (2012). Calendar-effects and temperature-impacts in migratory waterbirds at three tropical Indian wetlands. Acta oecologica 43: 60-71; http://dx.doi. org/10.1016/j.actao.2012.05.009

Hazra, P., A. Sinha, A. Banerjee, P. Ghosh \& T.N. Khan (2014). Influence of photoperiod and temperature on the migration phenology of waterbirds at Santragachi Lake, West Bengal, India. NeBio 5(4): 4-14.

Helmers, D.L. (1992). Shorebird Management Manual. Western 
Shorebird Reserve Network. Monomet. MA, 58pp.

Johnson, M.G. (1965). Estimates of fish populations in warmwater streams by the removal method. Transactions of the American Fisheries Society 94: 350-357; http://dx.doi.org/10.1577/15488659(1965)94[350:EOFPIW]2.0.CO;2

Khan, T.N. (2010). Temporal changes to the abundance and community structure of migratory waterbirds in Santragachhi Lake, West Bengal, and their relationship with water hyacinth cover. Current Science 99: 1570-1577.

Khan, T.N., A. Sinha, D. Basu \& S. Chakraborty (2005). A preliminary observation of diversity and threats to the survival of migratory waterfowls in an avian abode near Kolkata. Journal of Natural History 1: 56-67.

Ludwig, J.A. \& J.F. Reynolds (1988). Statistical Ecology: A Primer on Methods and Computing. John Wiley \& Sons, New York, 202pp.

Ma, Z., B. Li, B. Zhao, K. Jing, S. Tang \& J. Chen (2004). Are artificia wetlands good alternatives to natural wetlands for waterbirds? - A case study on Chongming Island, China. Biodiversity and Conservation 13: 333-350.

Maiti, S., S. Balachandran \& S. Chaudhury (2010). Interdependency of macrophytes and avian diversity in the wetlands of Ballavpur Wildlife Sanctuary, Santiniketan. Science and Culture 76: 180-184.

McCune, B. \& J.B. Grace (2002). Analysis of ecological communities. Gleneden Beach: MjM Software Design.

McCune, B. \& M.J. Mefford (2006). PC-ORD. Multivariate analysis of ecological data, Version 5. Gleneden Beach: MjM Software.

Moser, M., C. Prentice \& S. Frazier (1996). A global overview of wetland loss and degradation, pp. 21-31. In: Technical Session B of the 6th Ramsar Conference of Parties. Brisbane.

Okes, N.C., P.A.R. Hockey \& G.S. Cumming (2008). Habitat use and life history as predictors of bird responses to habitat change. Conservation Biology 22: 151-162; http://dx.doi.org/10.1111/ j.1523-1739.2007.00862.x

Pannekoek, J. \& A. van Strien (2001). TRIM (Trends and Indices for Monitoring Data). Centraal Bureau voor de Statistiek (CBS), Vooburg, NL, Research paper no. 1020), 57pp.

Peters, K.A. \& D.L. Otis (2007). Shorebird roost-site selection at two temporal scales: is human disturbance a factor? Journal of Applied Ecology 44: 196-209; http://dx.doi.org/10.1111/j.13652664.2006.01248.x

Petit, L.J. \& D.R. Petit (1996). Factors governing habitat selection by prothonotary warblers: field tests of the Fretwell-Lucas models. Ecological Monographs 66: 367-387; http://dx.doi. org/10.2307/2963523

Rendon, M.A., A.J. Green, E. Aquilera \& P. Aalmaraz (2008). Status, distribution and long-term changes in the waterbird community wintering in Doñana, south-west Spain. Biological Conservation 141: 1371-1388; http://10.1016/j.biocon.2008.03.006

Sarkar, B., P. Hazra, S. Pawan Kumar, Piu Ghosh, A. Banerjee \& T.N. Khan (2014). Habitat Attributes and Waterbird-Use of Four Wetlands in Manas National Park, Assam, India. Proceedings of the Zoological Society 67: 94-107; http://dx.doi.org/10.1007/s12595-013-0074-3

Sinha, A., P. Hazra \& T.N. Khan (2011). Diversity, Population Trends and Spatiotemporal Changes to the Community Structure of Waterbirds in Birbhum District, West Bengal, India. Proceedings of the Zoological Society 64: 96-108; http://dx.doi.org/10.1007/ s12595-011-0018-8
Sinha, A., P. Hazra \& T.N. Khan (2012). Emergence of a wetland with the potential for an avian abode of global significance in South Bengal, India. Current Science 102: 613-616.

Shine, C. \& C. Klemm (1999). Wetlands, Water and the Law: Using Law to Advance Wetland Conservation and Wise Use. IUCN, Cambridge, UK.

Soulliere, G.J. \& M.J. Monfils (1996). Waterbird use of a constructed wetland complex in eastern upper Michigan. Wildlife Division Report No. 3262. Michigan Department of Natural Resources, 12pp.

Studds, C.E. \& P.P. Marra (2007). Linking fluctuations in rainfall to nonbreeding season performance in a long-distance migratory bird, Septophaga ruticilla. Climate Research 35: 115-122; http://dx.doi. org/10.3354/cr00718

Taft, O.W., M.A. Colwell, C.R. Isola \& R.J. Safran (2002). Waterbird responses to experimental drawdown: implications for the multispecies management of wetland mosaics. Journal of Appled Ecology 39: 987-1001; http://dx.doi.org/10.1046/j.13652664.2002.00763.x

Taft, O.W. \& S.M. Haig (2003). Historical wetlands in Oregon's Willamette valley implications for restoration of winter waterbird habitat. Wetlands 23: 51-64; http://dx.doi.org/10.1672/02775212(2003)023[0051:HWIOWV]2.0.CO;2

Takekawa, J.Y., S.R. Heath, D.C. Douglas, W.M. Perry, S. Javed, S.H. Newman, R.N. Suwal, A.R. Rahman, B.C. Choudhury, D.J. Prosser, B. Yan, Y. Hou, N. Batbayar, T. Natsagdorj, C.M. Bishop, P.J. Butler, P.B. Frappell, W.K. Milsom, G.R. Scott, L.A. Hawkes \& M. Wikelski (2009). Geographic Variation in Bar-headed Geese Anser indicus: Connectivity of Wintering Areas and Breeding Grounds Across a Broad Front. Wildfowl 59: 100-123.

Terborgh. J. (1985). Habitat selection in Amazonian birds, pp. 311340. In: Cody, M.L. (ed.). Habitat Selection in Birds. Academic Press, London.

Tourenq, C., R.E. Bennets, H. Kowalski, E. Vialet, J.L. Licchesi, Y. Kayser \& P. Isenmann (2001). Are rice fields a good alternative to natural marshes for waterbird communities in the Camargue, southern France? Biological Conservation 100: 335 -343; http://dx.doi. org/10.1016/S0006-3207(01)00037-4

Wetlands International (1997). The Asian Waterfowl Census. Wageningen, 24pp.

Wetlands International (2006). Waterbird Population Estimates (4 ${ }^{\text {th }}$ ed.) Wetlands International, The Netherlands, 177pp.

Wetlands International (2009). Status of Waterbirds in Asia: Results of the Asian Waterbird census 1987-2007. Malaysia, 276pp.

Wetlands International (2010). Guidance on waterbird monitoring methodology: Field Protocol for waterbird counting, 15pp.

Zhang Y., M. Hao, J.Y. Takekawa, F. Lei, B. Yan, D.J. Prosser, D.C. Douglas, Z. Xing \& S.H. Newman (2011). Tracking the Autumn Migration of the Bar-Headed Goose (Anser indicus) with Satellite Telemetry and Relationship to Environmental Conditions. International Journal of Zoology Volume 2011 (Article id 323847): 10pp; http://dx.doi. org/10.1155/2011/323847 
Appendix 1. Location and major attributes of three wetlands of southern Bengal studied during the period from 1998 to 2013. The estimates represent the 16-year means \pm Standard Deviation (DO = Dissolved oxygen content; Zoopl. = Zooplankton abundance; Macroin. = Macroinvertebrate abundance; Macroph. = Macrophyte abundance).

\begin{tabular}{|c|c|c|c|c|c|c|c|c|}
\hline Wetland & Location & $\begin{array}{c}\mathrm{DO} \\
(\mathrm{mg} / \mathrm{l})\end{array}$ & $\begin{array}{l}\text { Zoopl. } \\
\text { (no./l) }\end{array}$ & $\begin{array}{l}\text { Macroin. } \\
\left(\text { no. } / \mathrm{m}^{2}\right)\end{array}$ & $\begin{array}{c}\text { Fish } \\
\left(\mathrm{no} . / \mathrm{m}^{2}\right)\end{array}$ & $\begin{array}{l}\text { Macroph. } \\
\left(\mathrm{g} / \mathrm{m}^{2}\right)\end{array}$ & $\begin{array}{l}\text { Area } \\
\text { (ha) }\end{array}$ & $\begin{array}{l}\text { Depth } \\
\text { (m) }\end{array}$ \\
\hline Bakreswar* & $\begin{array}{l}23.832-23.854^{\circ} \mathrm{N} \\
\& 87.390-87.423^{\circ} \mathrm{E}\end{array}$ & $5.81 \pm 0.57$ & $27.42 \pm 1.31$ & $20.75 \pm 0.93$ & $14.70 \pm 0.46$ & $33.61 \pm 1.21$ & $592 \pm 9.5$ & $3.65 \pm 0.04$ \\
\hline Hinglo\# & $\begin{array}{l}23.821-23.845^{\circ} \mathrm{N} \\
\& 87.181-87.208^{\circ} \mathrm{E}\end{array}$ & $6.39 \pm 0.57$ & $25.77 \pm 0.41$ & $20.94 \pm 1.12$ & $15.67 \pm 0.38$ & $33.74 \pm 0.57$ & $392 \pm 9.5$ & $3.32 \pm 0.04$ \\
\hline Adra@ & $\begin{array}{l}23.573-23.587^{\circ} \mathrm{N} \\
\& 86.832-86.846^{\circ} \mathrm{E}\end{array}$ & $6.08 \pm 0.16$ & $21.87 \pm 0.15$ & $15.75 \pm 0.86$ & $13.71 \pm 0.14$ & $29.72 \pm 0.18$ & $262 \pm 4.2$ & $3.45 \pm 3.45$ \\
\hline
\end{tabular}

Bakreswar* - Partly protected rural reservoir flanked by croplands and villages; Sewage discharge negligible

Hinglo\# - Rural reservoir flanked by intensively barren rocky areas and cultivated agricultural lands; runoff negligible

Adra@ - Sub-urban man-made Lake inside unprotected forest lands; waste discharge and runoff negligible

Appendix 2. Details of (a) waterbird census and (b) their food-base sampling schedules followed every year from 1998 to 2013 . To ensure an equal sampling effort every year in all the wetlands each observer-group included at least one person who was involved in these observations throughout the study period from 1998 to 2013

(a) Waterbird census schedule

\begin{tabular}{|l|c|c|c|c|c|}
\hline Wetland & $\begin{array}{c}\text { Date } \\
\text { (January) }\end{array}$ & $\begin{array}{c}\text { No. of } \\
\text { Observers }\end{array}$ & $\begin{array}{c}\text { No. of } \\
\text { Groups }\end{array}$ & $\begin{array}{c}\text { No. of } \\
\text { Vantage points }\end{array}$ & $\begin{array}{c}\text { Size of } \\
\text { Count unit (ha) }\end{array}$ \\
\hline Bakreswar Reservoir & 25 & 12 & 6 & 30 & 20 \\
\hline Hinglo Reservoir & 25 & 12 & 6 & 24 & 16 \\
\hline Adra Saheb Bandh Lake & 17 & 10 & 5 & 20 & 13 \\
\hline
\end{tabular}

(b) Waterbird food base sampling schedule

\begin{tabular}{|l|c|c|c|c|c|}
\hline Wetland & $\begin{array}{c}\text { Date } \\
\text { (January) }\end{array}$ & $\begin{array}{c}\text { No. of } \\
\text { Observers }\end{array}$ & $\begin{array}{c}\text { No. of } \\
\text { Groups }\end{array}$ & $\begin{array}{c}\text { No. of } \\
\text { Transects }\end{array}$ & $\begin{array}{c}\text { No. of } \\
\text { Sampling sites }\end{array}$ \\
\hline Bakreswar Reservoir & $26-27$ & 12 & 6 & $(6+6)=12$ & $(30+30)=60$ \\
\hline Hinglo Reservoir & $29-30$ & 12 & 5 & $(5+5)=10$ & $(25+25)=50$ \\
\hline Adra Saheb Bandh Lake & 18 & 12 & 6 & 8 & 40 \\
\hline
\end{tabular}

